\title{
Can Abundant Summer Precipitation Counter Losses in Herbage Production Caused by Spring Drought?
}

\author{
R. K. Heitschmidt ${ }^{1}$ and L. T. Vermeire ${ }^{2}$ \\ Authors are ${ }^{1}$ Supervisory Rangeland Scientist; and ${ }^{2}$ Ecologist, USDA Agricultural Research Service, \\ 243 Fort Keogh Road, Miles City, MT 59301.
}

\begin{abstract}
Drought is an inherent trait of most rangelands and sound management necessitates managers address two fundamental questions when facing a drought situation. The first question is, "what is the probability that a useful amount of precipitation will be received over the period of concern?" and the second question is, "if it does rain, what will the impact be in terms of quantity and quality of herbage produced?" The objective of this study was to address the second question. Our hypothesis was that herbage growth response to above normal summer precipitation (i.e., $2 \times$ in July and August) would be limited in the northern Great Plains because of a general absence of productive warm-season species. Study plots were twelve $5 \times 10$-m nonweighing lysimeters. Treatments were: 1) simulated (i.e., rainout shelter imposed), severe spring drought (i.e., 1 May - 1 July) followed by ambient precipitation thereafter; 2) simulated, severe spring drought followed by ambient precipitation thereafter plus summer irrigation (i.e., July and August); 3) ambient precipitation only; and 4) ambient precipitation plus summer irrigation. Results indicated substantial herbage production can be expected in this region during summer when precipitation is well above average because of the positive growth response of blue grama (Bouteloua gracilis [H.B.K.] Lag. ex Griffiths), the dominant warm-season grass growing in this region. However, results also showed that level of production in the study situation (i.e., spring drought, wet summer) was only about $50 \%$ of that attained in a normal (i.e., wet spring/dry summer) year. Moreover, long-term weather data shows the probability of receiving $2 \times$ normal precipitation in both July and August (i.e., our irrigation treatments) is $<1 \%$. Thus, although these rangelands possess the capacity to respond favorably to summer precipitation, the low probability of receiving substantial levels of summer precipitation ensures levels of ecological and economic risk remain high.
\end{abstract}

\section{Resumen}

La sequía es una característica inherente de la mayoría de los pastizales y un manejo sensato requiere de que los manejadores aborden dos cuestiones fundamentales cuando encaran una situación de sequía. La primer cuestión es: “¿cual es la probabilidad de que una cantidad útil de precipitación sea recibida durante el periodo de preocupación?” y la segunda es: “si llueve, ¿cual será el impacto en términos de cantidad y calidad del forraje producido?” El objetivo de este estudio fue abordar la segunda cuestión. Nuestra hipótesis fue que el crecimiento de forraje en respuesta a precipitaciones arriba de lo normal en verano (esto es, 2 veces mayor en Julio y Agosto) estaría limitado, en las Grandes Planicies del Norte, por una ausencia general de especies productivas de estación caliente. Las parcelas de estudio fueron lísimetros de no peso de $5 \times 10 \mathrm{~m}$. Los tratamientos evaluados fueron: 1 ) sequía severa simulada (con protectores de precipitación) en primavera (del 1 de Mayo al 1 de Julio), seguida por un ambiente de precipitación; 2) sequía severa simulada en primavera seguida por un ambiente de precipitación mas irrigación en verano (en Julio y Agosto); 3) ambiente de precipitación solamente y 4) ambiente de precipitación mas irrigación. Los resultados indican que, en esta región, durante el verano se puede esperar una producción substancial de forraje cuando la precipitación es arriba de lo normal debido a la respuesta positiva de crecimiento del "Blue grama" (Bouteloua gracilis (H.B.K.) Lag. Ex Griffiths), el zcate dominante de estación caliente de esta región. Sin embargo, los resultados también mostraron que el nivel de producción en la situación de estudio (es decir primavera con seca y verano húmedo) fue solo aproximadamente $50 \%$ de la obtenida en un año normal (primavera húmeda/veano seco). Mas aún, los datos de clima de largo plazo muestran que la probabilidad de recibir 2 veces la precipitación normal en Julio y Agosto (esto es nuestros tratamientos de irrigación) es $<1 \%$. Así, aunque estos pastizales poseen la capacidad de responder favorablemente a la precipitación de verano, la baja probabilidad de recibir niveles substanciales de precipitación en verano asegura que los niveles de riesgo ecológico y económico permanezcan altos.

Key Words: drought management, forage quality, grassland, primary production, northern Great Plains, soil water, species composition

Research was conducted under a cooperative agreement between USDA Agriculture Research Service and the Montana Agriculture Experiment Station. Mention of a proprietary product does not constitute a guarantee or warranty of the product by USDA, Montana Agriculture Experiment Station or the authors and does not imply its approval to the exclusion of other products that may also be suitable.

USDA - ARS Northern Plains Area is an equal opportunity/affirmative action employer and all agency services are available without discrimination.

Correspondence: R. K. Heitschmidt, USDA Agriculture Research Service, 243 Fort Keogh Road, Miles City, MT 59301. Email: rod@larrl.ars.usda.gov.

Manuscript received 29 September 2005; manuscript accepted 7 May 2006. 


\section{INTRODUCTION}

Drought is an inherent trait of most rangelands, and therefore, effective rangeland management must include drought management strategies that minimize ecological and economic risks. But because most rangeland managers are eternal optimists when it comes to rainfall expectations, they often fail to respond to drought in a timely manner, and as such, they often expose themselves to unnecessary risks (Riechers et al. 1989; Holechek 1996; Thurow and Taylor 1999).

There are two fundamental questions rangeland managers need to address when in a drought situation. The first is, "what is the probability that an effective amount of precipitation will be received in the immediate future?" The reason this is a fundamental question is because of the obvious positive linkage between precipitation and herbage production (Sala and Lauenroth 1982, Sala et al. 1988, Mcauliffe 2003, Neilson 2003). Ready access to site, season, and amount specific precipitation probabilities based on long-term weather records (e.g., see http://www.hprcc.unl.edu/wrcc/states/mt.html) provides managers with critical information for improving drought management decisions. But in addition to this information, research throughout the northern Plains region has shown also that herbage production is driven largely by spring precipitation (Sims et al. 1978; Sims and Singh 1978a, 1978b; Singh et al. 1982). More specifically, research at Miles City has shown that $91 \% \pm 16 \mathrm{SD}$ of annual perennial grass production is normally produced by July 1 (Heitschmidt and Vermeire 2005). Thus, we believe that by combining this information with precipitation probability information, regional rangeland management personnel can initiate effective drought management tactics in early July with considerable confidence if the situation so dictates.

But even so, only a limited number of rangeland managers in this region will choose to implement drought management tactics in early July because, "it may rain next week, and if it does ...." So the second question is, "if it does rain, what will the impact be on current year's herbage production?" The answer to this question is key for developing effective drought management strategies across most rangelands because: 1 ) most rangelands are either arid or semi-arid (i.e., seasonal drought is "normal"); and 2) optimism reigns when considering the probability of receiving significant, fruitful precipitation in the not-too-distant future. The specific objective of this research was to address the second question relative to the northern Great Plains region. Our hypothesis was that the summer production capacity of these grasslands, following spring drought, would be quite limited because of a general absence of productive warm-season perennial grasses. In addition, we hypothesized that quality of forage (i.e., nitrogen content) would vary in direct proportion to the relative amounts of live and dead tissue which in turn would vary largely as a function of precipitation regimen.

\section{METHODS}

\section{Study Area}

Research was conducted during the 2004 growing season at the Fort Keogh Livestock and Range Research Laboratory located near Miles City, MT (lat $46^{\circ} 22^{\prime} \mathrm{N}$, long $105^{\circ} 5^{\prime} \mathrm{W}$, elev. $725 \mathrm{~m}$ ). Regional topography ranges from rolling hills to broken badlands with small intersecting streams that seasonally drain into large permanent rivers meandering through broad, nearly level valleys. The potential natural vegetation on the 22,500-ha station is a grama-needlegrass-wheatgrass (Bouteloua-Stipa-Agropyron) mixed grass dominant (Küchler 1964). Long-term annual precipitation averages $340 \mathrm{~mm}$ with about $60 \%$ received during the 150 -day, mid-April to mid-September growing season (Fig. 1). Average daily temperatures range from $-10^{\circ} \mathrm{C}$ in January to $24^{\circ} \mathrm{C}$ in July with daily maximum temperatures occasionally exceeding $37^{\circ} \mathrm{C}$ during summer and daily minimums occasionally dropping below $-40^{\circ} \mathrm{C}$ during winter.

\section{Study Plots and Treatments}

Study plots were $12,5 \times 10-\mathrm{m}$ non-weighing lysimeters constructed in 1992 on a gently sloping $(4 \%)$ clayey range site (USDA 2003). Soils were Kobase silty clay loam, fine, montmorillonitic, frigid, Aridic Ustochrepts. Lysimeters were arranged perpendicularly to the slope along a $65-\mathrm{m}$ transect in two groups of six lysimeters each with a $5-\mathrm{m}$ area between groups. They were created by filling $12-\mathrm{cm}$ wide by $2-\mathrm{m}$ deep perimeter trenches and associated $15-\mathrm{cm}$ tall wooden foundations, with urethane foam insulation. Each lysimeter was equipped with two soil water monitoring access tubes centrally positioned in the upper and lower half of each lysimeter.

An automated rainout shelter was used to develop spring drought conditions, a pre-requisite for the successful conduct of this study, since normal to above normal herbage production during spring would curtail interest and reliance on herbage production during summer. Drought conditions were developed by controlling the amount of precipitation received on six of the 12 lysimeters (Larson et al. 1993). The $12-\times 35-\mathrm{m}$ metal-framed "roof" was mounted on $15-\mathrm{cm}$ diameter plastic wheels atop seven $5-\mathrm{cm}$ wide rails extending about $75 \mathrm{~cm}$ above the soil surface. Rails extended from top edge (i.e., upslope) to about $15 \mathrm{~m}$ below the bottom edge of the lysimeters. Rails were located directly over lysimeter borders. The shelter was equipped with a moisture sensitive conductance plate that when wetted, activated an electric motor and its associated drive system, which moved the shelter across the plots. For a more detailed description of the physical layout of the rainout shelter and lysimeters, see Heitschmidt et al. (1999, 2005).

Randomly assigned, thrice replicated treatments were: 1) simulated spring drought (i.e., no precipitation from 1 May to 1 July) followed by ambient conditions until end of growing season (i.e., 1 October) hereafter referred to as SDNI wherein $\mathrm{SD}=$ simulated, severe spring drought, $\mathrm{N}=$ no, and $\mathrm{I}=$ irrigation; 2) simulated spring drought plus supplemental water during summer (July and August) followed by ambient conditions until end of growing season (SDI); 3) ambient conditions throughout year, hereafter referred to as MDNI wherein $\mathrm{MD}=$ moderate drought because ambient precipitation (Fig. 1) during the study resulted in a moderate drought; and 4) ambient conditions during spring and fall plus supplemental water in July and August (MDI). 

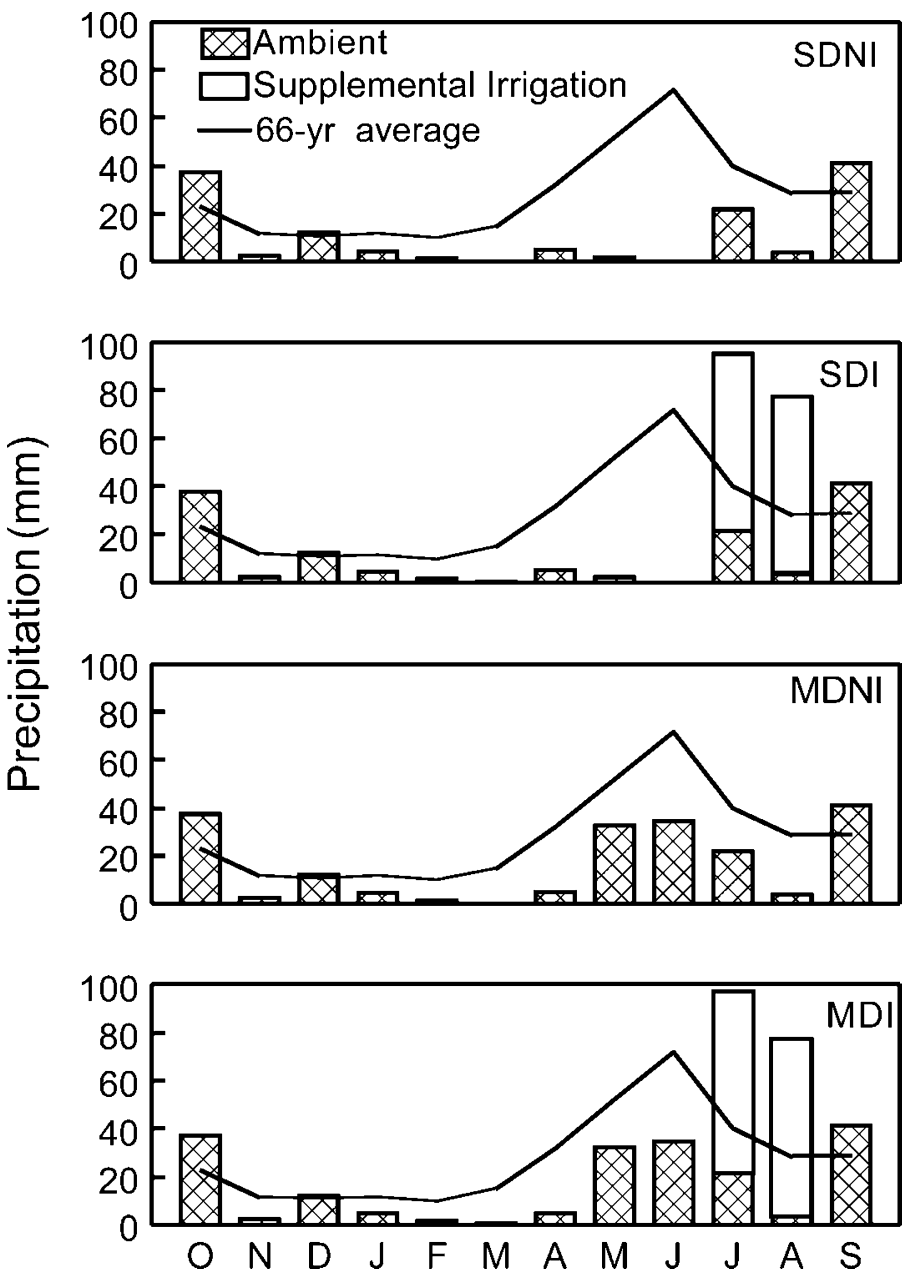

Figure 1. Monthly long-term average precipitation at Miles City, MT (NOAA 2004) and ambient precipitation (at study site, April through November, and at Miles City airport, December through March) and supplemental irrigation water from October 2003 through September 2004 for severe drought, non-irrigated (SDNI), severe drought, irrigated (SDI), moderate drought, non-irrigated (MDNI), and moderate drought irrigated (MDI) treatments.

Irrigated plots were watered in mid- and late July and August 2004. Water was from the Miles City municipal water supply and was applied evenly across plots using a garden hose delivery system and a hand held nozzle. During each of the four irrigation events, $38 \mathrm{~mm}\left(1.5^{\prime \prime}\right)$ of water was applied resulting

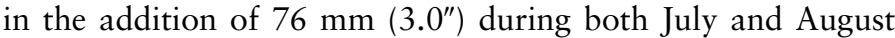
(i.e., $152 \mathrm{~mm}$ total irrigation). This amount is about $225 \%$ of the 69-year average precipitation amounts for July $(40.4 \mathrm{~mm})$ and August $(28.4 \mathrm{~mm})$ and $275 \%$ of the 69 -year year median precipitation for July $(32.8 \mathrm{~mm})$ and August $(22.6 \mathrm{~mm})$. Rate of application was about $25 \mathrm{~mm} \cdot \mathrm{hr}^{-1}$. Within each event, four applications were made, three late afternoon of the same day and one early the next morning, with each application lasting about 25 minutes, the time required to fully saturate surface soils.

Study plots were located inside a 30 -ha enclosure that had not been grazed by livestock since 1988 . However, the study plots per se had been grazed infrequently by sheep over the last
11 years depending upon previous research protocols (Heitshmidt et al. 1999, 2005). Study plots were not grazed in this experiment.

\section{Sampling Procedures}

Precipitation was monitored on site using three standard rain gauges. Soil water was measured a minimum of once per month from April to October and immediately before and after each irrigation event. Estimates were obtained at depths of 15, 30, 60 , and $90 \mathrm{~cm}$ using a fully calibrated, dielectric soil water probe (Troxler Sentry $200 \mathrm{AP}$ ).

Aboveground standing crop was measured monthly May through October by clipping $10,250-\mathrm{cm}^{2}$ circular quadrats per lysimeter. Five quadrats each were located randomly along two randomly located transects, one in the up-slope half of the lysimeter and the other in the down-slope half. Permanent records of quadrat locations were used to insure no repeat clipping of any quadrat during the year. Before harvesting standing crops, visual estimates of relative abundance (i.e., abundant, common, or sparse) were assigned to all species within each quadrat. Only the most abundant species were clipped individually with most species combined into functionally similar groups. Species and species groups were: western wheatgrass (Pascopyrum smithii Rydb. [Love]); needle-andthread grass (Hesperostipa comata [Trin. \& Rupr.] Barkworth); warm-season perennial shortgrasses, which was dominated by blue grama (Bouteloua gracilis [H. B. K.] Lag. ex Griffiths) with a scattering of buffalograss (Buchloe dactyloides [Nutt.] Engelm.); other warm-season perennial grasses, of which sand dropseed (Sporobolus cryptandrus [Torr.] A. Gray) and tumblegrass (Schedonnardus paniculatus [Nutt.] Trel.) were the dominant species; Bromus spp., which was principally Japanese brome (Bromus japonicus Thunb. ex Murr.) with a small amount of downy brome (Bromus tectorum L.); other cool-season perennial grasses, of which Sandberg's bluegrass (Poa sandbergii Vasey) was dominant; other cool-season annual grasses, of which sixweeks fescue (Vulpia octoflora [Walt.] Rydb.) and little barley (Hordeum pusillum Nutt.) were dominant, and forbs. Herbage was dried at $60^{\circ} \mathrm{C}$ for a minimum of 48 hours before weighing. Amounts of live (i.e., green) and dead (i.e., brown) tissue were estimated by hand separation.

Total nitrogen content was estimated by tissue class (i.e., live [green] and dead [brown]) for both western wheatgrass and the pool of warm-season perennial shortgrasses which was dominated by blue grama. Because amounts of harvested herbage within a treatment replication (i.e., lysimeter) were frequently insufficient to conduct C-N laboratory analyses, like samples were pooled across replicates within treatments and dates prior to analyses. Total nitrogen content was determined using a C-N analyzer (Carlo-Erba, C. E. Elantech, Inc., Lakewood, $\mathrm{NJ}$ ) following grinding to pass through a $1-\mathrm{mm}$ Wiley Mill screen.

\section{Data Analyses}

Herbage aboveground net primary production (ANPP) was estimated by summing increases in live herbage within four functional groups: 1) cool-season perennial grasses (CSPG); 2) 

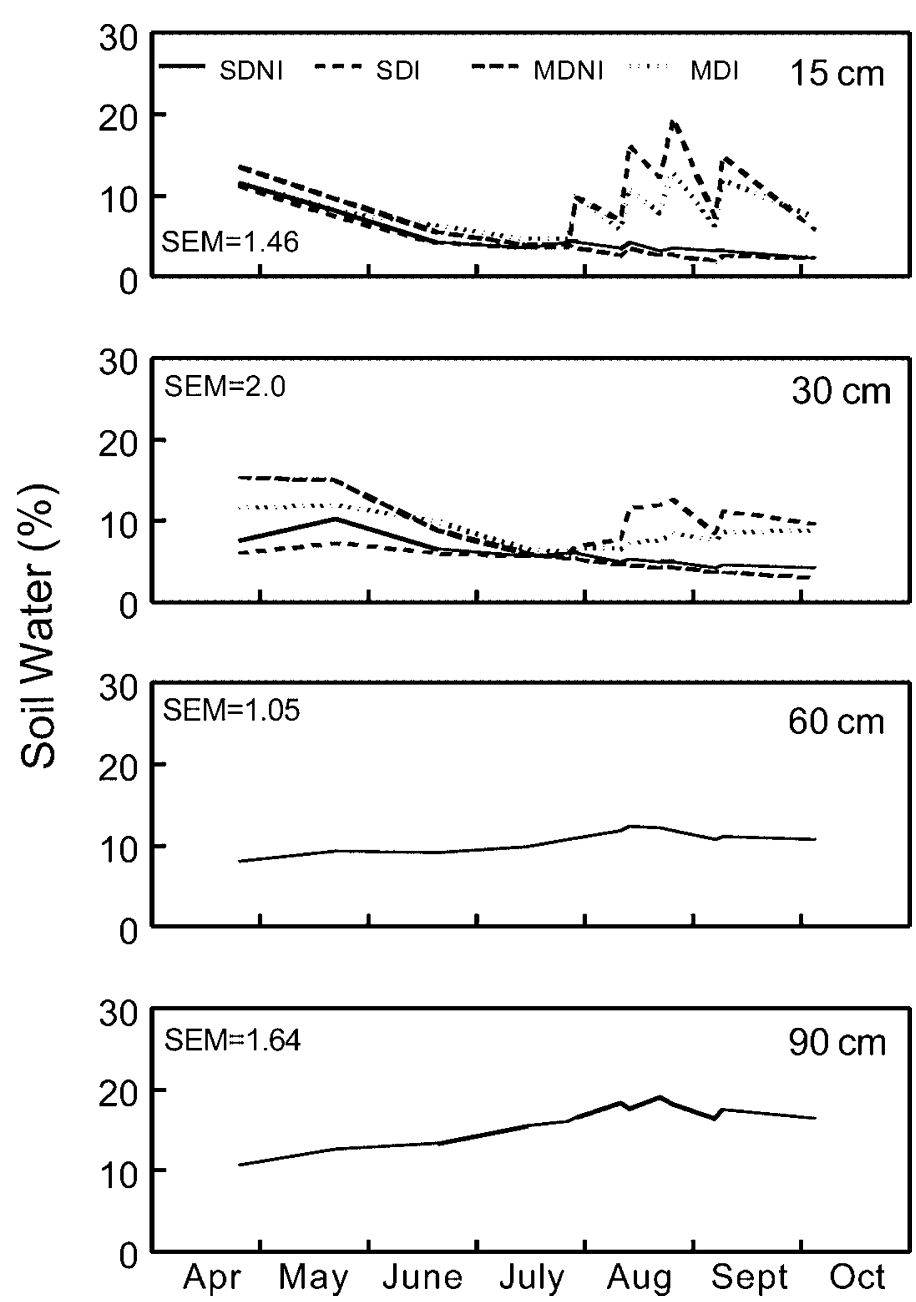

Figure 2. Soil water estimates (\%) at 15-, 30-, 60- and 90-cm depths for severe drought, non-irrigated (SDNI), severe drought, irrigated (SDI), moderate drought, non-irrigated (MDNI), and moderate drought irrigated (MDI) treatments. SEM = standard error of the mean.

cool-season annual grasses (CSAG); 3) warm-season perennial grasses (WSPG); and 4) forbs (FORB). Total production was estimated by summing functional group estimates. Proportional live and dead standing crops were multiplied by live and dead $\% \mathrm{~N}$, then summed and multiplied by 6.25 to estimate whole plant crude protein (\%CP) by replicate.

Data were statistically analyzed using SAS MIXED analysis of variance procedures (Littell et al. 1996). The complete randomized design, repeated measures models included the main effects of water treatment (fixed) and date (random) and their interaction. All data sets were analyzed for normality using the Shapiro-Wilk test. Data sets identified as not normally distributed were FORB primary productivity estimates, soil water at all four (i.e., 15, 30, 60, and $90 \mathrm{~cm}$ ) depths, and all three (live, dead, and total) standing crop data sets. All non-normal distribution data sets were log-transformed for analyses, but are presented as arithmetic means to facilitate interpretation. Significant interactions were followed by tests of simple effects at $\mathrm{P} \leq 0.05$. In addition, PROC GLM regression procedures were used to identify relationships between whole plant \%CP (dependent variable) and live/dead ratios (independent variable) (SAS 1990).

\section{RESULTS}

\section{Precipitation and Soil Water}

Ambient precipitation throughout this study was $42 \%$ below average with a total of $197 \mathrm{~mm}$ received during the 12-month period from October 2003 to September 2004 as compared to the long-term average of $340 \mathrm{~mm}$ (Fig. 1). Monthly precipitation was at or above average for only 3 months (i.e., October and December 2003, September 2004) during the entire year and below average the remaining 9 months. Even with the 76.2 $\mathrm{mm}$ of supplemental water applied in July and August to the SDI and MDI treatments (i.e., SDI $=284 \mathrm{~mm}, \mathrm{MDI}=324$ $\mathrm{mm})$, total water (i.e., precipitation + irrigation) during the study year remained below the long-term average.

Soil water dynamics were closely tied to the various precipitation regimens (Fig. 2). Soil water content at the $15-\mathrm{cm}$ depth steadily declined, regardless of treatment, until mid-July when the first $39 \mathrm{~mm}$ of water were applied to the SDI and MDI treatments. Post-irrigation soil water percolation rates tended to be greater in the SDI than MDI treatment as reflected by the greater amounts of soil water present at the $15-\mathrm{cm}$ depth the day after irrigation and by the greater amounts that eventually percolated through to the $30-\mathrm{cm}$ depth. The reasons for this difference were unclear, but we suspect evapotranspiration (ET) rates may have been greater in the MDI than SDI treatment since it had greater amounts of live, actively growing biomass until late August (Fig. 3).

Depletion rates during spring at the $30-\mathrm{cm}$ depth followed the same pattern as at the $15-\mathrm{cm}$ depth although there were some differences $(\mathrm{P}<0.05)$ among treatments in soil water content early in the spring. Soil water increases following the mid-July irrigation were neither as dramatic nor as rapid at the $30-\mathrm{cm}$ depth as at the $15-\mathrm{cm}$ depth. There were no significant $(\mathrm{P}>0.12)$ differences among treatments in soil water content at the 60- and 90-cm depths. There were significant $(\mathrm{P}<0.01)$ date effects at both depths as slight increases in soil water were noted as the growing season progressed and supplemental irrigation was begun in mid-July, but neither the 60-nor $90-\mathrm{cm}$ treatment-by-date interaction effect was significant $(P>0.20)$.

\section{Aboveground Herbage Dynamics}

Herbage dynamics clearly reflected anticipated treatment effects relative to amounts of live, dead, and total herbage (Fig. 3 ). Total herbage remained near constant in the severe drought treatments (SDNI and SDI) during spring and was dominated by dead material. This was in contrast to the moderate drought treatments (MDNI and MDI) wherein total herbage increased with the production of live herbage. During summer and early autumn, total herbage in the non-irrigated treatments (SDNI and MDNI) decreased and was dominated by dead material. This is in contrast to the irrigated treatments (SDI and MDI) wherein total herbage increased with the production of live material.

\section{Aboveground Net Primary Production}

The severe, season-long drought conditions simulated in the SDNI treatment severely limited aboveground net primary production (ANPP) with total ANPP being $267 \mathrm{~kg} \cdot \mathrm{ha}^{-1}$ which was significantly $(\mathrm{P}=0.049)$ less than the average of 892 


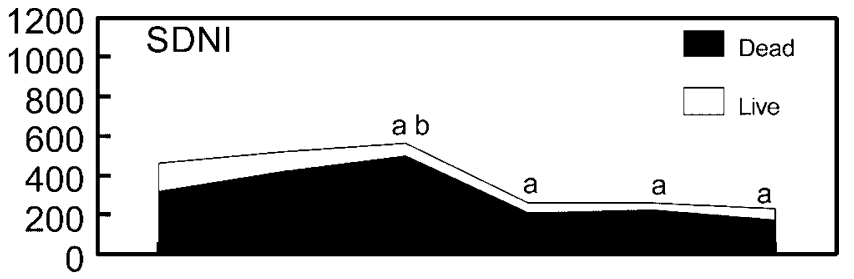

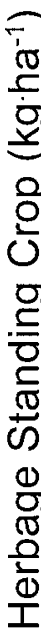
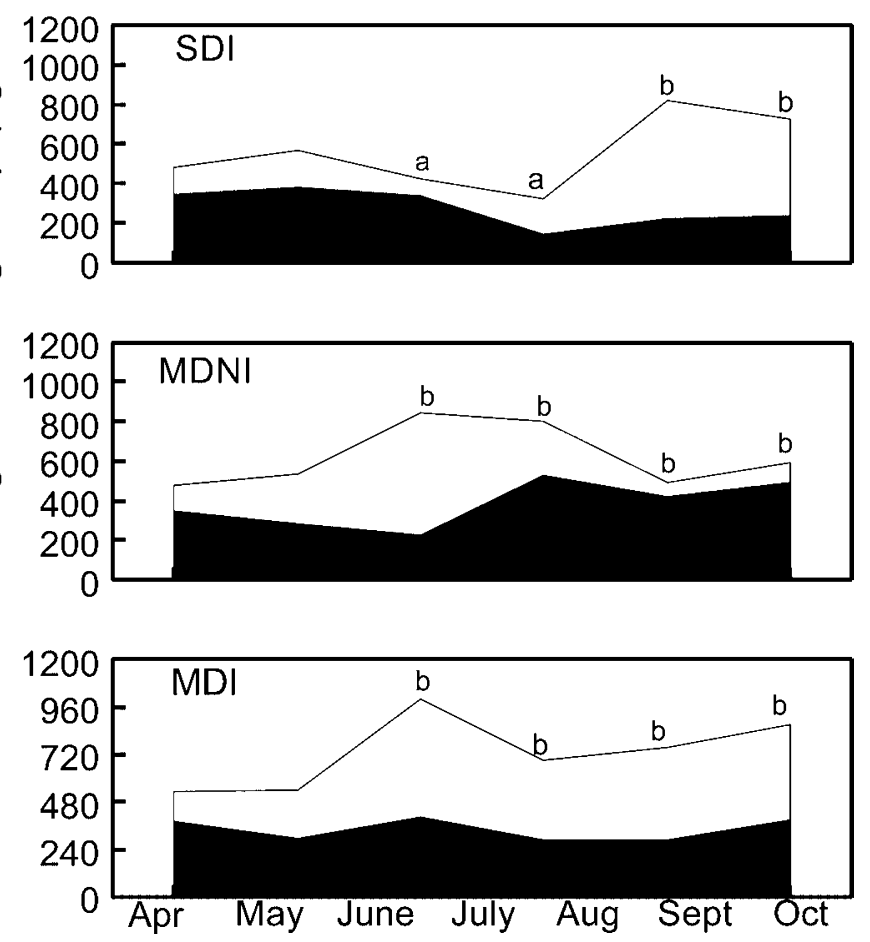

Figure 3. Estimated live, dead, and total herbaceous standing crop for severe drought, non-irrigated (SDNI), severe drought, irrigated (SDI), moderate drought, non-irrigated (MDNI), and moderate drought irrigated (MDI) treatments. Within date total standing crop treatment means with different letters are significantly different at $P \leq 0.05$.

$\mathrm{kg} \cdot \mathrm{ha}^{-1}$ for the SDI, MDNI, and MDI treatments (Fig. 4). Differences in total ANPP were the result of varying functional group responses to the differing precipitation regimens in that summer irrigation (SDI and MDI) significantly $(\mathrm{P}<0.01)$ increased WSPG of which blue grama was the overwhelming dominant. The other significant difference was in FORB production wherein severe spring drought (SDNI and SDI) significantly suppressed production $(\mathrm{P}<0.03)$, particularly that of the dominant species wooly plaintain (Plantago patagonica Jacq.). There were no significant $(\mathrm{P}>0.05)$ differences among treatments in either CSPG or CSAG production.

\section{Herbage Quality}

Whole-plant western wheatgrass \%CP estimates varied significantly $(\mathrm{P}<0.02)$ by treatment, date and their interaction. Temporal trends (Fig. 5) closely followed community level changes in amounts of live and dead tissue (Fig. 3) with average $\%$ CP being least during spring in the severe drought treatments (SDNI and SDI) when dead tissue was dominate and greatest in summer in the irrigated treatments (SDI and MDI) when live tissue was dominant. A notable exception to this generalization

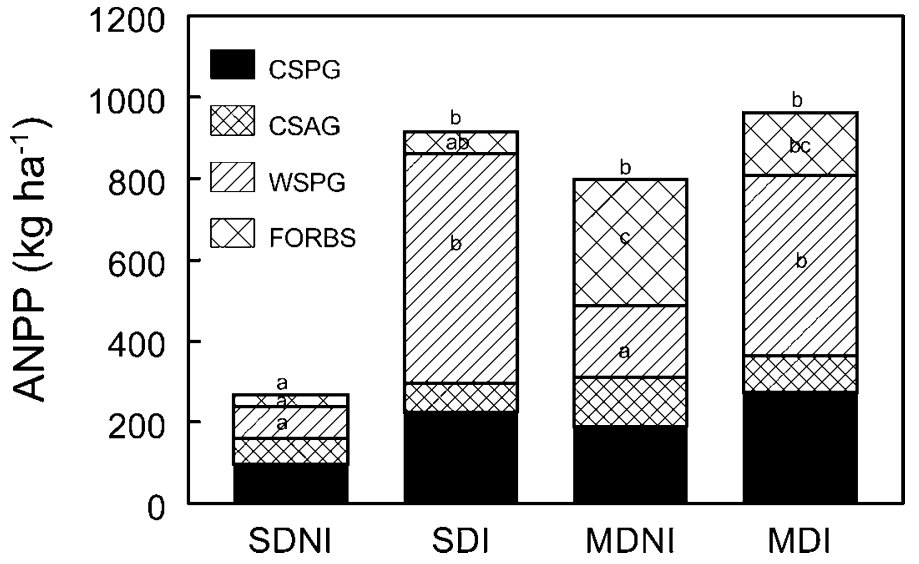

Figure 4. Estimated aboveground net primary productivity (ANPP) for cool-season perennial grasses (CSPG), cool-season annual grasses (CSAG), warm-season perennial grasses (WSPG), and forbs (FORBS) in severe drought, non-irrigated (SDNI), severe drought, irrigated (SDI), moderate drought, non-irrigated (MDNI), and moderate drought irrigated (MDI) treatments. Total and species groups treatment means with different letters are significantly different at $\mathrm{P} \leq 0.05$.

was the greater than expected \%CP estimate for June in the SDI treatment. Close examination of this data point revealed estimated CP concentrations for both live and dead tissue were slightly greater in the SDI than SDNI treatment as were estimates for live:dead ratios. But when these non-significant $(\mathrm{P}>0.05)$ differences were combined to estimate whole plant $\% \mathrm{CP}$, a significant $(\mathrm{P}<0.05)$ difference emerged. As expected, the correlation between whole plant \%CP and live:dead estimates was significant $(\mathrm{P}<0.01, r=0.33, \mathrm{n}=68)$. However, the rather low $r^{2}$ value $(0.11)$ indicated that factor(s) other than "greenness" were also affecting \% CP estimates.

Whole plant \%CP analyses of the pool of warm-season perennial shortgrasses also varied $(\mathrm{P}<0.01)$ by treatment, date, and their interaction effect, and as with western wheatgrass, treatment effects (Fig. 5) mimicked the effects of community level changes in amounts of live and dead tissue (Fig. 3). The resulting effect was that temporal trends tended to mimic those for western wheatgrass except during fall when estimated $\% \mathrm{CP}$ was greater in the non-irrigated (SDNI and MDNI) than irrigated treatments (SDI and MDI). The reason for this was because October \%CP estimates for both live and dead tissue were substantially greater in the non-irrigated than irrigated treatments (live $=20.8 \%$ vs. $10.8 \%$, dead $=10.0 \%$ vs. $8.0 \%$ ) We assume this was because the average age of these tissues, particularly the live tissue, was substantially less in the nonirrigated than irrigated treatments. Evidence in support of this explanation is that live tissue standing crop increased in the non-irrigated treatments $55 \%$ from early September to early October whereas it declined $47 \%$ in the irrigated treatments. In addition, if it is assumed that September precipitation (Fig. 2) spurred equal amounts of growth in all treatments, then it can be reasoned that the greater quality in the nonirrigated treatments was because the small amount of young, high quality, perennial shortgrass tissue added to the small pool of older, live tissue present in the non-irrigated treatments (34 $\mathrm{kg} \cdot \mathrm{ha}^{-1} \pm 12 \mathrm{SE}$ ) increased whole plant \% CP estimates more than the addition of an equal amount of tissue into the larger 

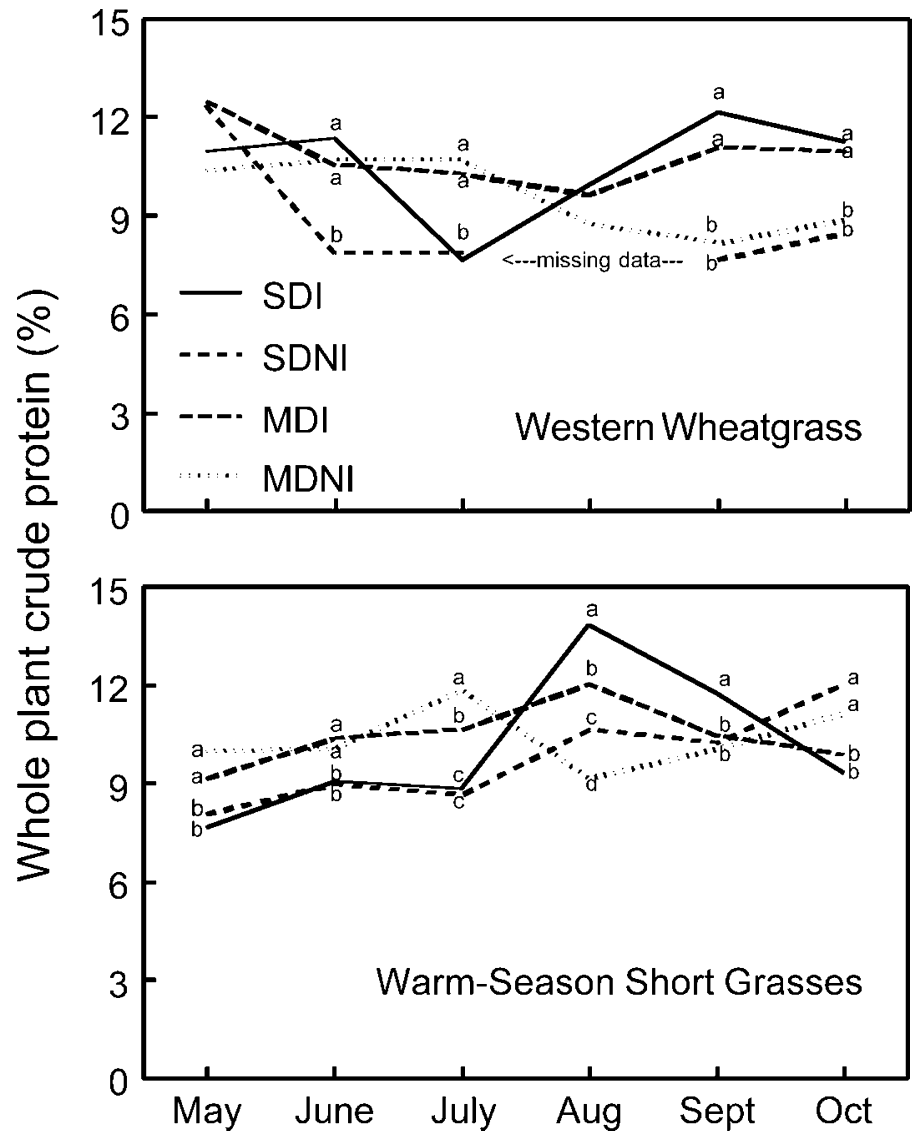

Figure 5. Monthly whole plant crude protein estimates (\%) for western wheatgrass and warm-season perennial shortgrasses in severe drought, non-irrigated (SDNI), severe drought, irrigated (SDI), moderate drought, non-irrigated (MDNI), and moderate drought irrigated (MDI) treatments. Total and species groups treatment means with different letters are significantly different at $\mathrm{P} \leq 0.05$.

pool of older, live tissue present in the irrigated treatments (317 $\left.\mathrm{kg} \cdot \mathrm{ha}^{-1} \pm 26 \mathrm{SE}\right)$. Regression analyses of the pool of warmseason perennial shortgrasses revealed a significant relationship between \% CP and live:dead ratios $(\mathrm{P}<0.01, r=0.51, \mathrm{n}=$ $71)$ as was the case with western wheatgrass.

\section{DISCUSSION}

It was imperative that our experimental design include at least two spring drought treatments to test our hypothesis that the production capacity of these grasslands during summer, following spring drought, would be limited because of a general absence of productive warm-season perennial grasses. In retrospect, we recognize we could have met our study objective without the two simulated, severe drought treatments because the absence of normal amounts of ambient precipitation produced a moderate spring drought (Fig. 1). Thus, results from both the two simulated severe drought treatments (SDNI and SDI) and the two ambient, moderate drought treatments (MDNI and MDI) address our hypothesis. For example, study results showed that regardless of drought treatment: 1) soil water content (Fig. 2) and herbage (Fig. 3) dynamics were quite similar until supplemental water was added in July and August whereafter both soil water content and herbage production increased significantly in the irrigated treatments (SDI and MDI); and 2) total ANPP was similar among treatments except for the significantly greater amount of warm-season perennial grass produced in the irrigated treatments than non-irrigated treatments (Fig. 4). However, the magnitude of differences in warm-season perennial grass production between the simulated severe drought treatments was considerably greater than the magnitude of differences between the moderate drought treatments (Fig. 4). For example, in the moderate drought treatments, irrigation increased warm-season perennial grass production by $251 \%$ (176 vs. $443 \mathrm{~kg} \cdot \mathrm{ha}^{-1}$ ) whereas in the severe drought treatments, irrigation increased production by $716 \%$ (79 vs. $566 \mathrm{~kg} \cdot \mathrm{ha}^{-1}$ ).

We acknowledge that the severity of the simulated drought was extreme for the northern Great Plains. This is evidenced by: 1 ) there is $>90 \%$ chance that at least $5 \mathrm{~mm}$ of precipitation will be received at this location in each of the months of April, May, and June (http://www.hprcc.unl.edu/wrcc/states/mt.html); and 2) total herbage production in the SDNI was only 267 $\mathrm{kg} \cdot \mathrm{ha}^{-1}$ or about $33 \%$ of total production in the MDNI treatment. Still, the response to summer irrigation was equivalent $(\mathrm{P}>0.05)$ in the severe drought treatment (SDI) to that in the moderate drought treatment (MDI) in terms of both total production and functional group composition (Fig. 4). Presumably, this was because soil water in all treatments was near equal by July 1 (Fig. 2), thus insuring the occurrence of similar post-July 1 production responses to both ambient and supplemental water treatments.

An important question relative to these conclusions is, "do these grasslands have the capacity to produce herbage during summer in an amount equivalent to normal spring production?" To address this question, we examined 8 years of herbage production data from non-manipulated control plots used in previous studies conducted within these same study plots (Heitschmidt et al. 1999, 2005). Estimated ANPP for those 8 years averaged $2072 \mathrm{~kg} \cdot \mathrm{ha}^{-1}$ with an average composition of $55 \%$ cool-season perennial grasses $\left(1140 \mathrm{~kg} \cdot \mathrm{ha}^{-1}\right), 25 \%$ warm-season perennial grasses $\left(520 \mathrm{~kg} \cdot \mathrm{ha}^{-1}\right), 10 \%$ coolseason annual grasses $\left(207 \mathrm{~kg} \cdot \mathrm{ha}^{-1}\right)$, and $10 \%$ forbs $(207$ $\mathrm{kg} \cdot \mathrm{ha}^{-1}$ ). This is in contrast to the current study wherein estimated ANPP for the moderate drought, irrigated treatment (MDI) was $984 \mathrm{~kg} \cdot \mathrm{ha}^{-1}$ with a compositional mix of $28 \%$ cool-season perennial grasses $\left(273 \mathrm{~kg} \cdot \mathrm{ha}^{-1}\right), 46 \%$ warmseason perennial grasses $\left(443 \mathrm{~kg} \cdot \mathrm{ha}^{-1}\right), 10 \%$ cool-season annual grasses $\left(92 \mathrm{~kg} \cdot \mathrm{ha}^{-1}\right)$, and $16 \%$ forbs $\left(156 \mathrm{~kg} \cdot \mathrm{ha}^{-1}\right)$. Thus, it appears that ample summer precipitation will not enhance annual production to a level that fully off-sets production losses resulting from spring drought. In fact, it is rather surprising that warm-season perennial grass production with ample summer precipitation was essentially the same (443 vs. $520 \mathrm{~kg} \cdot \mathrm{ha}^{-1}$ ) as that in an average, nondrought year.

Although the results of this study are from one specific site, findings are applicable to a relatively broad region of the northern Great Plains. This is because much of the northern Great Plains is dominated by cool-season perennial grasses with an accompanying spring/early summer growing season and associated precipitation pattern (Küchler 1964; Sims et al. 
1978; Sims and Singh 1978a, 1978b; Singh et al. 1982; Klement et al. 2001). Thus, the criterion validating the applicability of these results to other sites or regions should be the occurrence of precipitation peaks during spring and early summer and a substantial decrease in precipitation after early July. To this end, we examined the probabilities of receiving $50.8 \mathrm{~mm}$ (2 inches) of precipitation in July, August, and September for numerous locations across the northern Great Plains using the long-term weather records (http://www.hprcc.unl.edu/wrcc/ states/mt.html). We arbitrarily established a probability of 0.25 for receiving $50.8 \mathrm{~mm}$ (2.0 inches) within a 30-day period for defining regions wherein the results of this research were directly applicable. Based on these criteria, the defined area included essentially all of the non-mountainous area of Wyoming and the non-mountainous area east of the continental divide of Montana. In addition, we found numerous instances where juxtapositioned areas met a less restrictive probability of 0.35 for receiving $50.8 \mathrm{~mm}$ over any given 30 -day period in July, August, and September.

The results of this study support our hypothesis that forage quality, as measured by crude protein concentration (Fig. 5), is tied closely to herbage "greenness" (Huston and Pinchak 1991; Heitschmidt et al. 1995; Haferkamp et al. 2005). However, the relatively low $r$ values from the regression of \% $\mathrm{CP}$ and live: dead ratios emphasize that factors other than "greenness" were affecting CP concentrations. This is in agreement with other findings (Huston and Pinchak 1991; Haferkamp et al. 2005) and serves to remind us that these relationships are complex and over simplification can lead to erroneous conclusions.

The results of this study also provide insight into the potential impacts of climate change on the structure and function of these grasslands. Our results, although short-term, indicate a shift in dominance from cool- to warm-season perennial grasses can be anticipated if the annual precipitation regimen were to shift from a dominance of spring precipitation to a dominance of summer precipitation. Similar types of shifts in plant species composition would be expected in most terrestrial ecosystems because seasonal availability of water is a key variable driving plant species composition as shown experimentally in the sagebrush steppe of Oregon (Svejcar et al. 2003), the southwestern oak savannah of Arizona (Weltzin and McPherson 2003), the tallgrass prairie of Kansas (Fay et al. 2003), and the shortgrass prairie of Colorado (Dodd and Lauenroth 1979).

\section{MANAGEMENT IMPLICATIONS}

The results of this study, in concert with the findings of Heitschmidt and Vermeire (2005), provide key information necessary to develop effective, proactive drought management strategies for a large region of the northern Great Plains. Specifically, results from this study show these grasslands have considerable capacity to produce herbage throughout the 5month growing season if growing conditions are favorable. However, the capacity appears to be capped at about $50 \%$ of the quantity of herbage that would normally be produced during a "normal" spring. We know from Heitschmidt and Vermeire (2005) that about $90 \%$ of perennial grass production is completed in this region by 1 July and that the probability of receiving substantial growing season precipitation after July 1 is low. Therefore, we believe ranchers and other rangeland managers can make critical stocking rate decisions in this region with confidence by early July thereby substantially reducing both ecological and economic risks during periods of drought.

\section{LITERATURE CITED}

Dodd, J. L., And W. K. Lauenroth. 1979. Analysis of the Response of a Grassland Ecosystem to Stress. In: N. French [ED.]. Perspectives in Grassland Ecology. Ecological Studies 32. New York, NY: Springer-Verlag Inc. p 43-58.

Fay, P. A., A. K. Knapp, J. M. Blair, J. D. Carlisle, B. T. Danner, and J. K. McCarron. 2003. Rainfall timing, soil moisture dynamics, and plant responses in a mesic tallgrass prairie ecosystem. In: J. F. Weltzin and G.R. McPherson [EDS.]. Changing precipitation regimes and terrestrial ecosystems - A North American perspective. Tucson, AZ: University of Arizona Press. $p$ 147-163.

Haferkamp, M. R., M. D. MacNeil, and E. E. Grings. 2005. Predicting nitrogen content in the northern mixed-grass prairie. Rangeland Ecology and Management 58:155-160.

Heitschmidt, R. K., E. E. Grings, M. R. Haferkamp, and M. G. Karl. 1995. Herbage dynamics on two northern Great Plains range sites. Journal of Range Management 48:211-217.

Heitschmidt, R. K., M. R. Haferkamp, M. G. Karl, and A. L. Hild. 1999. Drought and grazing: I. Effects on quantity of forage produced. Journal of Range Management 52:440-446.

Heitschmidt, R. K., K. D. Klement, and M. R. Haferkamp. 2005. Interaction effects of drought and grazing on northern Great Plains rangelands. Rangeland Ecology and Management 58:11-19.

Heitschmidt, R. K., and L. T. Vermelre. 2005. An ecological and economic risk avoidance drought management decision support system. In: J. A. Milne [ED.]. Pastoral systems in marginal environments. Proceedings of the satellite workshop of the $20^{\text {th }}$ International Grassland Congress; 3-6 July 2005; Glasgow, Scotland. The Netherlands: Wageningen Academic Publ. $178 \mathrm{p}$.

HoleCHEK, J. L. 1996. Drought and low cattle prices: hardship for New Mexico ranchers. Rangelands 18:11-13.

Huston, J. E., and W. E. Pinchak. 1991. Range animal nutrition. In: R. K. Heitschmidt and J. W. Stuth [EDS.]. Grazing management: an ecological perspective. Corvallis, OR: Timber Press. p 27-63.

Klement, K. D., R. K. Heitschmidt, and C. E. Kay. 2001. Eighty years of vegetation and landscape changes in the northern Great Plains - a photographic record. Washington, DC: USDA Agricultural Research Service Conservation Research Report No. 45. 91 p.

KüCHLER, A. 1964. Potential natural vegetation of the coterminous United States. New York, NY: American Geographical Society. Special Publication 36. 116 p.

LaRson, W., R. Heitschmidt, AND B. Knapp. 1993. Rainout shelter design. Transactions of the American Society of Agricultural Engineers (Mimeo handout).

Littell, R. C., G. A. Mılliken, W. W. Straup, and R. D. Wolfinger. 1996. SaS system for mixed models. Cary, NC: SAS Institute, Inc. 633 p.

Mcauliffe, J. R. 2003. The interface between precipitation and vegetation. In: J. F. Weltzin and G. R. McPherson [EDS.]. Changing precipitation regimes and terrestrial ecosystems. Tucson, AZ: University of Arizona Press. p 9-27.

National Oceanic and Atmospheric Administration. 2004. Climatological Data Annual Summary Montana. Asheville, NC: US Department of Commerce 107:10-11.

Neilson, R. P. 2003. The importance of precipitation seasonality in controlling vegetation distribution. In: J. F. Weltzin and G. R. McPherson [EDs.]. Changing precipitation regimes and terrestrial ecosystems. Tucson, AZ: University of Arizona Press. p 57-71. 
Riechers, R. K., J. R. Conner, And R. K. Heitschmidt. 1989. Economic consequences of alternative stocking rate adjustment tactics: a simulation approach. Journal of Range Management 42:165-171.

SAlA, O. E., AND W. K. LAUenRoth. 1982. Small rainfall events: an ecological role in semiarid regions. Oecologia 53:301-304.

Sala, O. E., W. J. Parton, L. A. Joyce, and W. K. Lauenroth. 1988. Primary production of the central grassland region of the United States. Ecology 69:40-45.

SAS. 1990. SAS/STAT User's Guide. Version 6, Volume 2. Cary, NC: SAS Institute, Inc. $1686 \mathrm{p}$.

Sims, P. L., AND J. S. Singh. 1978a. The structure and function of ten western North American grasslands. II. Intra-seasonal dynamics in primary producer compartments. Journal of Ecology 66:547-572.

Sims, P. L., AND J. S. SinGH. 1978b. The structure and function of ten western North American grasslands. III. Net primary production, turnover and efficiencies of energy capture and water use. Journal of Ecology 66:573-597.

Sims, P. L., J. S. Singh, and W. K. Lauenroth. 1978. The structure and function of ten western North American grasslands. I. Abiotic and vegetational characteristics. Journal of Ecology 66:251-285.
Singh, J. S., W. K. Lauenroth, R. K. Heitschmidt, and J. L. Dodd. 1982. Structural and functional attributes of the vegetation of northern mixed prairie of North America. The Botanical Review 49:117-149.

Svejcar, T., J. Bates, R. Angell, and R. Miller. 2003. The Influence of Precipitation Timing on the Sagebrush Steppe Ecosystem. In: J. K. Weltzin and G. R. McPherson [eds.]. Changing Precipitation Regimes and Terrestrial Ecosystems - A North American Perspective. Tucson, AZ: The University of Arizona Press. p 90-106.

ThuRow, T. L., AND C. A. TAYLOR. 1999. Viewpoint: the role of drought in range management. Journal of Range Management 52:413-419.

USDA, NRCS. 2003. Soil survey of Custer County, Montana. Part II. Washington, DC: US Department of Agriculture. $862 \mathrm{p}$.

Weltzin, J. F., and G. R. McPherson. 2003. Response of Southwestern Oak Savannas to Potential Future Precipitation Regimes - A North American Perspective. In: J. K. Weltzin and G. R. McPherson [eds.]. Changing Precipitation Regimes and Terrestrial Ecosystems - A North American Perspective. Tucson, AZ: The University of Arizona Press. $p$ 127-146. 